\title{
Syntactic and phonological phrasing in Bemba Relatives
}

\author{
Lisa Cheng \\ Leiden University \\ Nancy C. Kula \\ Leiden University (LUCL)
}

Tone as a distinctive feature used to differentiate not only words but also clause types, is a characteristic feature of Bantu languages. In this paper we show that Bemba relatives can be marked with a low tone in place of a segmental relative marker. This low tone strategy of relativization, which imposes a restrictive reading of relatives, manifests a specific phonological phrasing that can be differentiated from that of non-restrictives. The paper shows that the resultant phonological phrasing favours a head-raising analysis of relativization. In this sense, phonology can be shown to inform syntactic analyses.

\section{Introduction}

Relative clauses in Bantu have been a part of continued research dating back to Meeussen (1971). Various typologies and analyses that aim to capture the dependencies expressed in this clause type have been proposed (Givón 1972, Nsuka 1982, Walusimbi 1996). Despite the fact that there is overwhelming evidence of relative clauses formed by tone in various Bantu languages (Luganda, Kinyarwanda, Nsenga, Chichewa, Umbundu, Luba) hardly any analyses try to associate this fact to the syntactic analyses and generalisations proposed, but see Kamwangamalu (1988) for Luba.

This paper investigates (syntactic) analyses of relative clauses in Bantu, with particular reference to Bemba, that take recourse to phonological phrasing. We begin by outlining the strategies for relative clause formation in Bemba in section 2 for both subject and object relatives. In section 3 we look at the limitations of the tonal marking strategy as opposed to relatives marked with segmental relative markers. In section 4 and 5, we discuss the phonological phrasing in all relative types and its implications for the syntactic analyses of relative clauses. We finally, in section 6 , offer some concluding remarks. 


\section{Strategies for relative clause formation}

The formation of relative clauses in Bemba typically uses overt (i.e., segmental) relative markers. ${ }^{1}$ Subject relatives differ from object relatives in terms of the shape of the relative marker, the optionality of the relative marker, and the availability of the tonal marking strategy.

\subsection{Segmental relative markers}

In object relatives, the relative marker takes the shape of two of the four series of demonstratives (the hearer-proximate and the distal), but differs from these in terms of tone. While the two series of demonstratives concerned are both LowHigh in tone, the derived relative markers are High-Low. Their independent status is illustrated by the fact that the demonstrative and the relative marker (of the same class) can co-occur, as shown in (1)., ${ }^{2,3}$

$\begin{array}{lllll}\text { abántú abó } & \text { ábo } & \text { n-a-mwééne } & \text { maíló... } \\ \text { 2people } & \text { 2DEM } & \text { 2REL } & \text { 1SM-TNS-see.PERF } & \text { yesterday } \\ \text { 'those people who/that I saw yesterday...' } & \end{array}$

1 Our data sources are both from informants, for which we thank Fred Kula and Honoria Mutale, and from written sources. Our principal written sources are Sambeek (1955), Sharman (1956), Sharman and Meeusen (1955), Givón (1972) and Oger (1979). Bemba (M42) is spoken in the Northern and Copperbelt provinces of Zambia.

2 The following abbreviations are used in the glosses (numbers refer to agreement classes):

$\begin{array}{llll}\text { DEM } & \text { demonstrative } & \text { PERF } & \text { perfective } \\ \text { REL } & \text { relative marker } & \text { NEG } & \text { negative } \\ \text { TNS } & \text { tense } & \text { SG } & \text { singular } \\ \text { SM } & \text { subject marker } & \text { PPF } & \text { pre-prefix } \\ \text { OM } & \text { object marker } & \text { PFX } & \text { noun class prefix } \\ \text { STAT } & \text { stative } & \text { LOC } & \text { locative } \\ \text { COP } & \text { copular } & & \end{array}$

3 In the remainder of this paper we represent high tone with an acute accent and low tone with no marking. We are committed to saying there is tonal overwriting in Bemba evidenced by various tonal processes. For example, the low-toned verb stem peela 'give' has differing tones depending on whether it occurs before a high or a low-toned negative marker. Thus it remains low for the 1st person in the negative future: $n$-shà-kù-pèelè (SM1SG-NEG.TNS-OM2SG-give.PERF) 'I won't give you'; but is high in the negative past: $n$ shá-kú-péélè (SM1SG-NEG.TNS-OM2SG-give.PERF) 'I didn’t give you'. Similarly the floating low tone of the negative marker in the negative future overwrites a following prefixal high tone so that $t a$ '-bá-léké 'they won't stop' (NEG-2SM-TNS-stop.PERF) becomes tà-bà-léké. For ease of exposition, only inserted (or non-lexical) low tone will be marked with a falling accent while lexical low tone will remain unmarked. 
As seen in (1), segmental relative markers in object relatives, function as independent prosodic words on a par with demonstratives, and like the demonstrative pronouns, they agree with the head noun in class.

The segmental relative marker in subject relatives lacks this property of acting as an independent prosodic word. In fact, it is the pre-prefix in nominal agreement that subsumes the role of relative marker in subject relatives. As opposed to various Bantu languages that have lost the use of the pre-prefix, Bemba still utilizes it in the noun class system. Interestingly, the form [preprefix + noun class prefix] is identical to that of the proximate series of demonstratives (High-Low) (with a High-High tone pattern for the relative use). Consider the illustration of the pre-prefix as a noun class marker (2a), a relative marker (2b) and part of a demonstrative (2c).

(2) a. ú-lu-kásu

11PPF-11PFX-axe

'An axe'

b. ú-lu-kásu ú-lú-shítílwe léélo... 11PPF-11PFX-axe 11 PPF $=11$ REL-11SM-buy.PERF today 'The axe that has been bought today...'

$\begin{array}{ll}\text { c. ú-lu-kásu } & \text { úlu } \\ \text { 11PPF-11PFX-axe } & \text { 11DEM } \\ \text { 'This axe' } & \end{array}$

For the remainder of this article the distinction between independent and more clitic-like segmental relative markers, that are also referred to as relative concords in Bantu, can clearly be seen in the morphology but we label all relative markers simply as REL. For object relatives, the relative marker is in most cases optional (see below for exceptions). For subject relatives, the segmental relative marker can be replaced by changing the tone of the subject marker, which we argue to be a separate strategy, the tonal strategy.

\subsection{The tonal strategy}

Subject relatives have the option of either being marked by a pre-prefix segmental relative marker as illustrated in section 2.1, or by a tonal strategy that places a low tone on the subject marker. We propose to treat this low tone as a tonal morpheme that is functionally equivalent to its segmental counterpart. Consider the illustration of the tonal strategy in the paradigm in (3). (3a) is a 
simple sentence, showing that the subject marking/agreement on the verb is $b a$. (3b) illustrates subject relativization with the pre-prefix $a$ - as relative marker, while (3c) shows relativization with the low tone morpheme on the subject marker $b \grave{a}$-.

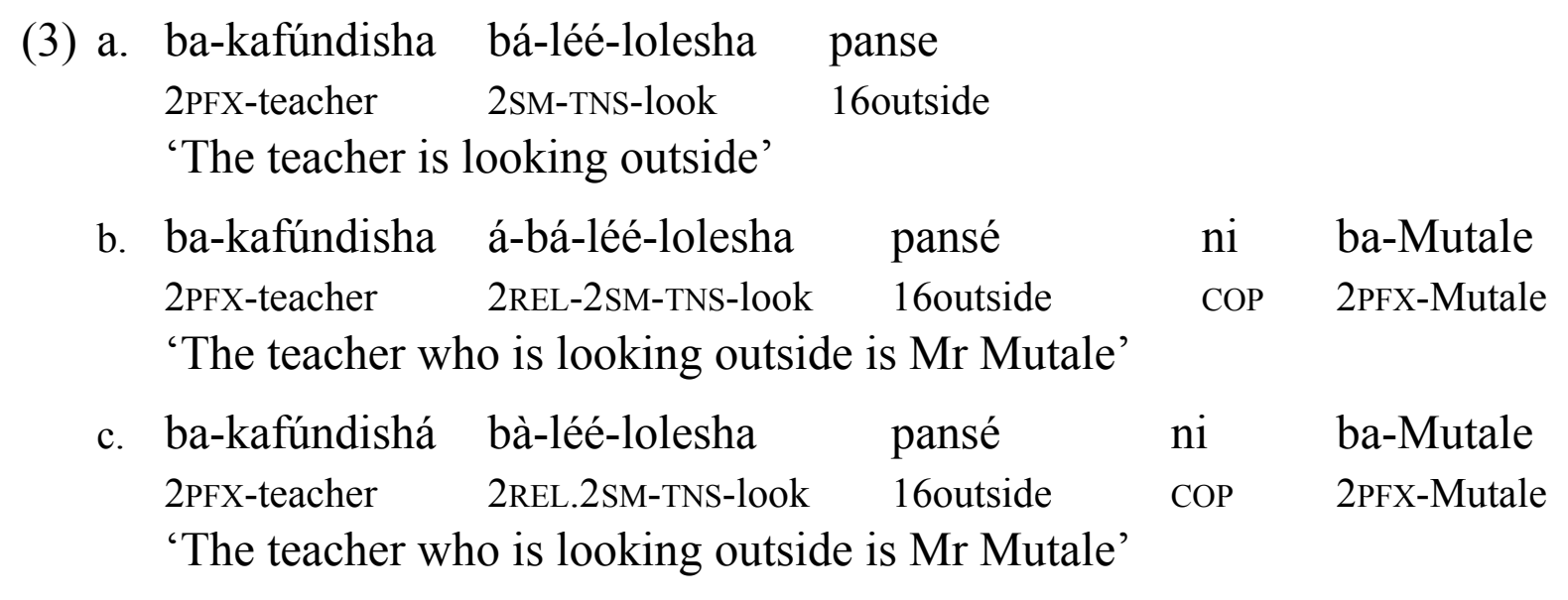

The fact that the subject agreement in (3a) consists of only the noun class prefix is not due to the fact that the noun also bears no pre-prefix. ${ }^{4}$ We get the same result with a noun that has a pre-prefix as in (4).
(4) ú-lu-kásu
lú-léé-kóntoka
11PPF-11 PFX-axe
11SM-TNS-break.STAT
'The axe is going to break'

Note that in (3c), the subject agreement marker has a low tone, in contrast with the high tone in (3a), and the relative marker is missing (cf. (2b)). Merely deleting the pre-prefix relative marker does not yield (3c) since the subject agreement marker carries a high tone (as in 3a). Notice further that when the relative clause is marked with a low tone (as in $3 \mathrm{c}$ ), the final vowel of the head noun surfaces with a high tone (compare $3 \mathrm{c}$ to $3 \mathrm{a}, \mathrm{b}$ ). To show that this high tone is not responsible for relativization, consider the sentence in (5) where the head noun has a final high tone but the subject marker in the relative clause remains high.
(5)* ba-kafúndishá bá-léé-lolesha panse ni ba-Mutale 2PFX-teacher 2REL.2SM-TNS-look 16outside COP 2SM-Mutale
Int: 'The teacher who is looking outside is Mr Mutale'

\footnotetext{
4 As pointed out to us by Thilo Schadeberg, proper names, honorific terms (such as teacher) and kinship terms if they take noun class prefixes at all, never use the pre-prefix, thus $* a$ ba-kafundisha is ungrammatical.
} 
The ungrammaticality of (5) confirms that the tonal strategy involves the insertion of a low tone on the subject agreement marker. We will return, in section 4, to the additional final high tone on the head noun in (3c).

As an independent strategy the tonal strategy can be used to distinguish a matrix independent sentence from a subject relative clause as in (6).

(6) a. umúkásháána á-ácí-móna banamayo léélo

'The girl saw the women today'

b. umúkáshááná à-ací-móna banamayo lééló...

1 girl REL.1SM-TNS-see 2woman today

'the girl who saw the women today...'

Here again, as in (3c), we see the high tone of the subject marker being overridden by a low tone, resulting in a relative clause in (6b).

\subsection{Optionality and tonal strategy}

We have described above the tonal strategy as a strategy involving the insertion of a low tone relative marker when there is no segmental marker marking the relative clause. The discussion above solely concerns subject relative clauses. In object relatives, the picture is a bit different in two respects. First, the segmental relative marker is always optional in object relatives. And second, the use of the tonal strategy is restricted to cases involving disambiguation. Let us consider these in turn. The examples in (7) show the optional nature of the segmental marker in object relatives. (7a) is the non-relative sentence from which the relatives $(7 b-c)$ are derived.
a. Chisanga á-mwééne abántu maílo Chisanga 1SM-see.PERF 2person yesterday 'Chisanga saw people yesterday'

b. abántu ábo Chisanga á-mwééne maíló, na-bá-ya 2person 2REL Chisanga 1SM-see.PERF yesterday TNS-2SM-go 'The people who Chisanga saw yesterday have gone'

c. abántú Chisanga á-mwééne maíló, na-bá-ya 2person Chisanga 1SM-see.PERF yesterday TNS-2SM-go

'The people who Chisanga saw yesterday have gone'

(7c) differs from (7b) only in that the relative marker ábo is omitted, and the clause headed by Chisanga is still a relative clause modifying the head noun abántu 'people'. 
Interestingly, as opposed to subject relatives, the tonal strategy cannot be used in these cases (7c), i.e., when the segmental relative marker is absent. If the subject agreement marker has low tone, the sentence becomes ungrammatical (as shown in (8a), compared with (7c)). The tonal strategy is still unacceptable even in subject-inverted object relatives as shown by the contrast between ( $8 \mathrm{~b})$ and $(8 \mathrm{c}) .^{5}$

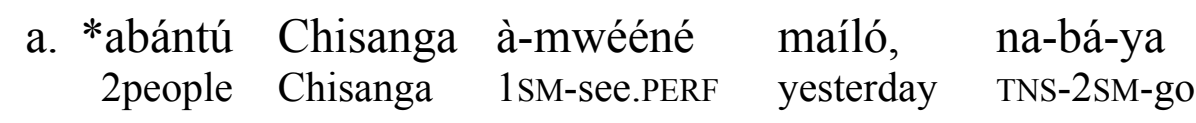
Int: 'The people who Chisanga saw yesterday have gone'
b. abántú á-mwééné
Chisanga
maíló, na-bá-ya 2people 1SM-see.PERF Chisanga yesterday TNS-2SM-go
(subj-inv)
'The people who Chisanga saw yesterday have gone'
c. *abántú à-mwééné Chisanga maíló, na-bá-ya (subj-inv+low T) 2people 1SM-see.PERF Chisanga yesterday TNS-2SM-go Int: 'The people who Chisanga saw yesterday have gone'

However, when the two arguments of the verb come from the same noun/agreement class as in (9) (umúluméndo and Chisanga are both in class 1), the tonal strategy can be used to mark relativization. Consider first the base sentence in (9a). In (9a), the relative marker $u$ o is present, marking the clause $a^{-}$ mwééne Chisanga mailo as a subordinate clause, modifying the head noun. Note that the relative clause involves subject-verb inversion.
a. umúluméndo úo á-mwééne Chisanga maílo lboy 1REL 1SM-see.PERF Chisanga yesterday
'the boy who Chisanga saw yesterday'
b. umúluméndo á-mwééne Chisanga maílo lboy 1SM-see.PERF Chisanga yesterday
'The boy saw Chisanga yesterday'
*'the boy (who) Chisanga saw yesterday'
c. umúluméndó à-mwééne Chisanga maílo 1boy 1REL.1SM-see.PERF Chisanga yesterday 'the boy who Chisanga saw yesterday'

Recall that in object relatives, the segmental relative marker is optional. However, in the case of (9a), if the relative marker is omitted, the sentence can no longer be interpreted as involving a relative clause. Instead, it is interpreted

5 The typical SV(O) order becomes V(O)S in the inverted case. See Demuth and Harford (1999), Harford and Demuth (1999) for discussion of subject inverted object relatives. 
as a simple sentence, as indicated in (9b). To mark such subject-inverted relatives without a relative marker is still possible: we resort to the tonal marking strategy, as in (9c). The tone on the subject agreement marker is no longer high, as in (9a); rather it is low, just as we have seen in subject relatives without a segmental relative marker. ${ }^{6}$

Without subject-verb inversion in the relative clause, the tonal strategy remains unavailable even when the two arguments of the verb are from the same noun/agreement class, as (10) shows.

(10) a. umúluméndó úo Chisanga á-mwééne maíló...

'the boy who Chisanga saw yesterday...'

b. umúluméndó Chisanga á-mwééne maíló... 'the boy (who) Chisanga saw yesterday...'

*'The boy saw Chisanga yesterday’

c. *umúluméndó Chisanga à-mwééne maíló... Int: 'the boy who Chisanga saw yesterday...'

Thus, we can conclude that in object relatives the tonal strategy is used only as a last resort when subject marking is unable to distinguish the subject from the object because they belong to the same class and moreover when word order can also not be relied upon to make the distinction. The tonal strategy is therefore only used in subject-inverted object relatives whose arguments belong to the same agreement class.

\section{$3 \quad$ Restrictions on the tonal marking strategy}

In addition to only being able to mark object relatives as a last resort used for purposes of disambiguation, there are further restrictions on the tonal marking strategy for relatives. The tonal strategy cannot be used to mark non-restrictive relatives or headless relatives. Let us look at this in more detail below.

\subsection{Restrictive versus non-restrictive relatives}

It turns out that whenever the tonal strategy is used, it necessarily leads to a restrictive reading of the relative clause. In contrast to this, the segmental relative marker strategy can have both non-restrictive and restrictive readings. Compare in this respect (11a) and (11b).

6 Sentence (9c) is ambiguous between a subject and object relative reading that relies on context for disambiguation. The subject relative interpretation of the sentence would be: 'the boy who saw Chisanga yesterday'. 

(11) a. abáBembá bà-shipa beekala muZambia (tonal strategy) 2Bembas 2REL.2SM-brave 2SM.live 18LOCZambia
'Brave Bembas live in Zambia (while those who aren't brave live elsewhere)' (restrictive only)
b. abáBemba á-bá-shipa beekala muZambia (seg REL) 2Bembas 2REL-2SM-brave 2sm.live 18LOCZambia
'Brave Bembas live in Zambia' (restrictive and non-restrictive)

In (11a), the relative clause bà-shipa 'that are brave', which is marked by the tonal morpheme (i.e., without a segmental relative marker), must be interpreted as a restrictive relative clause, restricting the reference of the head noun abáBembá. In contrast, (11b) with the relative clause á-bá-shipa 'that are brave' marked by the segmental relative marker, can be interpreted also as a nonrestrictive (in this case, equating Bembas with brave people).

In other words, the segmental relative markers in subject relatives can be used for both restrictive and non-restrictive relatives, but only the restrictive reading is possible when the tonal strategy is used.

When the head noun is a proper name, which in principle cannot be modified by a restrictive relative clause, the tonal marking strategy cannot be used (12b).

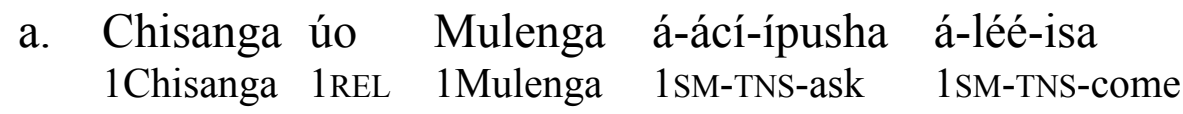

'Chisanga, who Mulenga invited, is coming' (non-restrictive) 1Chisanga 1REL.1SM-TNS-invite 1Mulenga 1SM-TNS-come (subj-inv)

Int: 'Chisanga, who Mulenga invited, is coming'

The tonal marking strategy therefore always induces a restrictive reading of the relative, or put differently, the tonal marking strategy cannot be used to mark non-restrictive relatives.

\subsection{Headless relatives}

Headless relatives in Bemba have the typical definite interpretation of a headless relative (see Grosu and Landman 1998). However, they do not have the free relative interpretation associated with the English counterpart whoever. ${ }^{7}$

7 To express the free relative interpretation, a quantificational element such as bonse 'all' has to be used, as shown below: 
Headless relatives are formed with segmental relative markers (a preprefix in the case of subject relatives and a demonstrative based relative marker in object relatives), as illustrated in (13).
a. á-bá-shipa béékala muZambia 2REL-2SM-brave 2SM.live 18LOCZambia 'those who are brave live in Zambia'
b. úo á-mwééne Chisanga maíló, na-á-fika 1REL 1SM-see.PERF Chisanga yesterday TNS-1SM-arrive 'the one who Chisanga saw yesterday has arrived'

The tonal strategy cannot be used to mark headless relatives in either subject or object relatives as the ungrammaticality of $(14 a, b)$ and $(15 a, b)$ shows, respectively.
a. *bà-shipa béékala muZambia 2REL.2SM-brave 2SM.live 18Zambia
'Those who are brave live in Zambia'
b. *à-ishílé maíló, ni Mutale 1REL.1SMcome.PERF yesterday COP Mutale
'The one who came yesterday is Mutale'
a. *à-mwééne Chisanga maíló, na-á-fika 1SM-see.PERF Chisanga yesterday TNS-1SM-arrive
'Who Chisanga saw yesterday has arrived'
b. *Chisanga à-mwééne maíló na-á-fika Int: 'Who Chisanga saw yesterday has arrived'

As seen for subject relatives in (14), it is impossible to omit the pre-prefixing relative marker and use the tonal marking strategy for headless relatives (cf. 13a). The same holds for object relatives, which we have shown to be able to employ the tonal strategy only for subject-inverted object relatives whose arguments belong to the same agreement class. In the inverted (15a), the tonal marking strategy remains unavailable.

(i) na-ali-temwa bonse ábo a-béésa

1SG.SM-TNS-love all 2DEM 2REL-2SM.come

Lit: 'I like all those who come'/ 'I like everyone who comes'

'I like whoever comes' 
To summarise thus far, subject relatives can utilize both the segmental relative marker strategy (noun-class pre-prefix) and the tonal strategy (low tone morpheme). Object relatives, on the other hand, primarily use a demonstrative based segmental relative marker that is in principle optional. The tonal strategy is only used as a last resort for disambiguation in subject-inverted object relatives when both the subject and object belong to the same noun class.

Since the low tone morpheme and the segmental relative marker both mark relativization they do not co-occur. The low tone morpheme is realised on the subject agreement marker, which is part of the verbal complex. Further, in both subject and object relatives the tonal marking strategy can only yield a restrictive relative clause interpretation, and it cannot be used at all in nonrestrictive relatives and headless relatives.

In the next section, we examine phonological phrasing in relatives involving different strategies. The data with phonological phrasing provide us with further insight into the inner workings of the tonal strategy.

\section{$4 \quad$ Phonological Phrasing}

Phonological phrasing in Bemba is generally marked by low tone and/or pause at the end of a phonological phrase. ${ }^{8}$ Like in Chichewa (see Kanerva 1990), constituents following the verb can, at least for high-toned verbs, be tonally characterised as not belonging to the same phonological phrase as the verb if the final high tone on the verb retracts. Tone retraction is indicative of a phonological phrase boundary so that when it does not take place (i.e., the verb ends in a high tone) the constituents following the verb phonologically phrase with the verb. This behaviour of disallowing high tone from being realized on a phrase final vowel, seems to be a diagnostic of phonological phrasing in Bemba as well. While the full details of Bemba phrasing and the range of strategies employed remain to be fully specified (Kula, in prep.), the two characteristics above suffice for the present exposition. Consider (16), which illustrates that the same sequence of words may have different phrasings in Bemba. (Phonological phrases (PPhs) will be indicated by parenthesis).

8 We follow in broad terms the basic assumptions of phrasal phonology as presented in for example Selkirk (1984), Nespor and Vogel (1986), that the largest constituent is the Utterance which itself consists of smaller constituents according to a prosodic hierarchy that ends with the prosodic word. Formation of these constituents is subject to the Strict Layer Hypothesis that prohibits improper bracketing, recursivity and non-exhaustiveness. We mainly focus here on phonological phrases and only briefly touch on intonational phrases. 


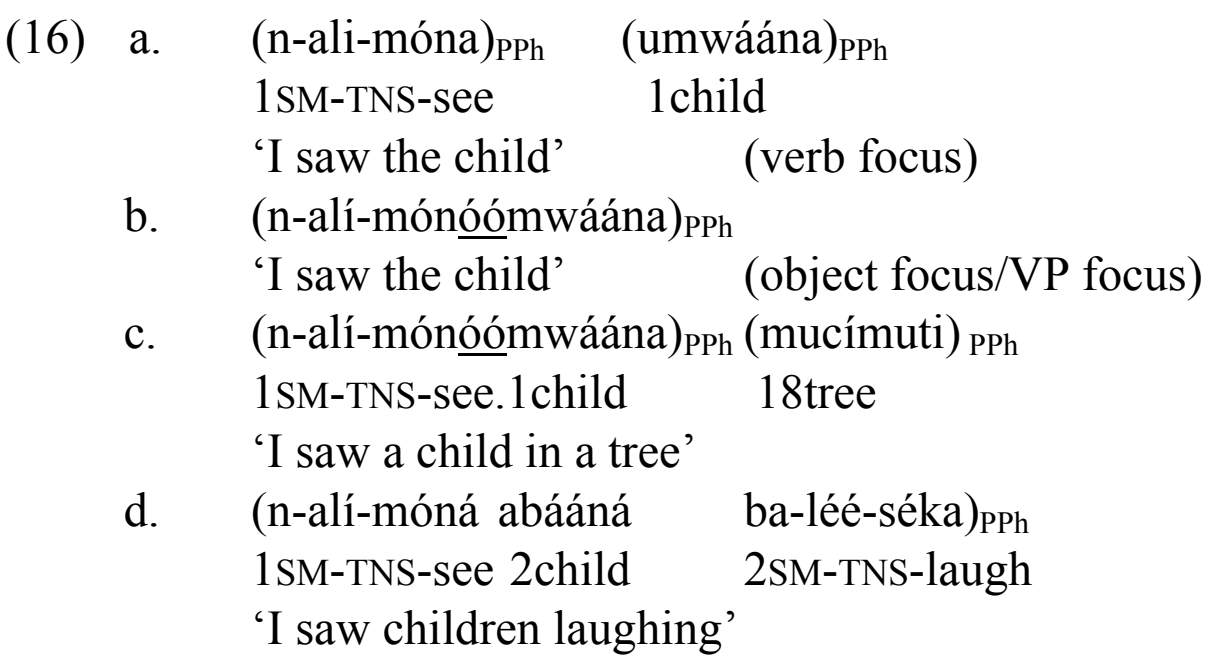

In (16a) with a focused verb, the verb is phrased separately from the object (the disjoint verb form), and as a result does not get final high tone. (16b) phrases the verb with the object (the conjoint verb form) and high tone on the verb final vowel can be seen on the resultant long vowel (underlined in (16b)) after fusion has taken place, indicating no phonological phrase break. This phrasing results in VP or object focus. Similarly, the fact that the [verb + object] complex in (16c) does not phrase with the following phrase is indicated by the low tone on the final syllable in the phonological phrase, in contrast to (16d).

The phrasing in relative clauses reveals that while a tonally marked relative must form a phonological phrase with its head noun (17a), i.e., it is always preceded by a high tone, relatives marked with a segmental relative marker have no such restriction and can be either phrased with the head noun $(17 \mathrm{c})$ or not (17d). (17) corresponds to (11): $(17 \mathrm{a}, \mathrm{b})$ show the tonal marking strategy and $(17 \mathrm{c}, \mathrm{d})$ the segmental marker strategy.
a. (abáBembá bà-shipa) $)_{\mathrm{PPh}}$ (beekala muZambia $)_{\mathrm{PPh}}$
(tonal REL)
b. *(abáBemba $)_{\mathrm{PPh}}(\text { bà-shipa })_{\mathrm{PPh}}$ (beekala muZambia $)_{\mathrm{PPh}}$
(tonal REL)
c. (abáBembá ábá-shipa) $)_{\mathrm{PPh}}$ (beekala muZambia) ${ }_{\mathrm{PPh}}$
(segmental REL)
d. (abáBemba) $)_{\mathrm{PPh}}(\text { ábá-shipa })_{\mathrm{PPh}}$ (beekala muZambia) $)_{\mathrm{PPh}}$ (segmental REL)

'Bembas who are brave live in Zambia'

In both (17a) and (17c) the final high tone on the head noun abáBembá indicates that the constituent following it is within the same phonological phrase as opposed to (17d) where this is not the case.

As we have indicated in section 3.1, relatives marked by segmental relative markers can be interpreted as restrictive or non-restrictive. The 
difference in interpretation also corresponds to a difference in phonological phrasing. (17c) in which the head noun and the relative clause form a phonological phrase yields a restrictive reading while (17d) yields a nonrestrictive reading. And note further that the tonal strategy (17a) only has a restrictive reading. In other words, if we consider phonological phrasing together with interpretation, we can conclude that a restrictive relative clause, be it tonally marked or marked by a segmental relative marker, requires that the head noun and the relative clause be in the same phonological phrase. Conversely, a non-restrictive relative clause forms a separate phonological phrase from the head noun.

The same phrasing asymmetries hold for object relatives. (18a) and (18b) differ in reading, though both are marked by a segmental relative marker. The former has a restrictive relative interpretation while the latter a non-restrictive interpretation. (18c) indicates the tonal strategy with phonological phrasing (necessarily for restrictives) and further that if the head noun was not phrased together with the verb the sentence would be ungrammatical. ${ }^{9}$
a. (abántú ábo Chísanga á-mwééne maílo) $)_{\mathrm{PPh}}\left(\right.$ na-bá-ya) ${ }_{\mathrm{PPh}}$
'The people who Chisanga saw yesterday have gone'
b. (abántu $)_{\mathrm{PPh}}(\text { ábo Chísanga á-mwééne maílo) })_{\mathrm{PPh}}$ (na-bá-ya) $)_{\mathrm{PPh}} \quad(=7 \mathrm{~b})$
'The people, who Chisanga saw yesterday, have gone'
c. (umúluméndó à-mwéené Chisanga maílo) ${ }_{\mathrm{PPh}}$ 'The boy who Chisanga saw yesterday'
d.* (umúluméndo) $)_{\mathrm{PPh}}\left(\right.$ à-mwéené Chisanga maílo) ${ }_{\mathrm{PPh}}$

Recall that in object relatives it is possible to optionally omit the segmental relative marker and a relative clause reading still obtains. The phrasings in these cases both with and without subject inversion are given in (19a-b). In both cases, the head noun has to be phrased together with the relative clause, and there is a mandatory restrictive reading of the relative clause. If the head noun and the verb are not phrased together as in (19c) a relative interpretation cannot be obtained.

9 We have, using PRAAT, phonetically produced sentences where the head noun ends in a low tone and is phrased separately from the verb in tonally marked object relatives. These have all been judged at best as strange and of unclear import. 

(19)
a. (abántú Chisanga á-mwééne maílo) PPh $_{\text {(na-bá-ya) }}$ PPh
b. (abántú á-mwééne Chisanga maílo) ${ }_{\mathrm{PPh}}$ (na-bá-ya) ${ }_{\mathrm{PPh}}$ 'The people that Chisanga saw yesterday have gone'
c. (abántu) $)_{\mathrm{PPh}}(\text { Chisanga á-mwééne maílo) })_{\mathrm{PPh}}$ (na-bá-ya) $)_{\mathrm{PPh}}$ 'The people Chisanga saw yesterday' *'The people who Chisanga saw yesterday’

This implies that object relatives without an overt segmental relative marker can never have a non-restrictive reading. This is further confirmed by data such as (20a-c) in which the head noun is a proper name, which forces a non-restrictive reading.
a. Mulénga úo Chísanga á-áci-tuma kumalíkééti na-á-bweela Mulenga REL Chisanga 1SM-TNS-send 17market TNS-1SM-return 'Mulenga who Chisanga sent to the market has returned'
b. \#Muléngá Chísanga á-áci-tuma kumalíkééti na-á-bweela Int: 'Mulenga, who Chisanga sent to the market, has returned' Lit: 'The Mulenga Chisanga sent to the market has returned'
c. \#Muléngá à-aci-tuma Chísanga kumalíkééti na-á-bweela

Both (20b) and (20c) lack a segmental relative marker. (20c) is marked by the tonal strategy while (20b) is completely unmarked. Note that for both (20b) and (20c), the head noun and the relative clause form one phonological phrase (with the head noun ending with a high tone). Both (20b) and (20c) are judged as odd because they require a restrictive reading of the proper name Mulenga.

We can thus conclude from the foregoing discussion that tonally marked relatives must be phrased together with the head noun. Since phrasing together with the head noun induces a restrictive reading of relatives, as can be seen also for segmentally marked relatives, tonally marked relatives always induce a restrictive reading and hence the strategy cannot be used for canonically nonrestrictive arguments.

\section{$5 \quad$ Implications for syntactic phrasing}

Given what we have seen in terms of phonological phrasing in relative clauses, we explore different analyses of relatives in this section. In particular, we consider the analysis for restrictives versus non-restrictives on the one hand, and headless relatives on the other. We show that phonological phrasing provides insight into which analysis of relative clauses makes the best syntax-phonology 
correspondence. Further, based on what we know about the structure of relative clauses, we make certain predictions about how phonological phrasing operates in Bemba.

\subsection{Restrictive vs. non-restrictive relatives}

Let us start by contrasting the standard structure (21a) for restrictive relative clauses with a Kaynian structure (21b) (Kayne 1994). ${ }^{10}$ The crucial difference between the two that we would like to draw on is that under the standard view the head noun is outside of the CP (i.e., CP is right-adjoined to the NP), which is the relative clause, while Kayne adopts a head-raising analysis where the head noun of the relative clause remains within the CP (and there is no adjunction structure). ${ }^{11}$

a.

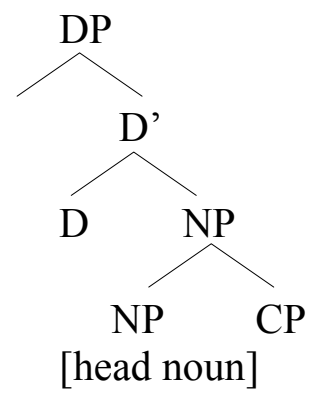

b.

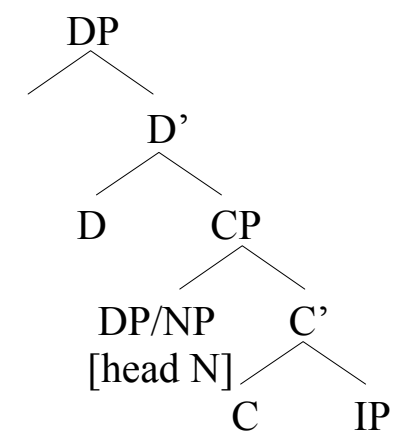

For a Bemba noun phrase such as (22a), the difference between the two analyses of relative clauses is where the $\mathrm{CP}$ boundary is. a. abántú ábo n-a-mwééne
2people 2REL 1SM-TNS-see.PERF
maíló... yesterday 'the people who I saw yesterday...'

b. [DP [NP abántú [ [C ábo n-a-mwééne maíló...]]] (standard)

c. [DP [cP abántú ábo n-a-mwééne maíló...]] (Kaynian)

As indicated by (22b), within the standard analysis, the CP boundary falls right before the relative marker ábo while in the Kaynian analysis, the CP boundary is right before the head noun abántú.

10 There are variations of the Kaynian structure, which we will not discuss in this article. See Bianchi (2000) among others.

11 It is harder to say where the relative clause begins in a Kaynian analysis. For $w h$-relatives, the relative pronoun is in SpecCP, while for that-relatives, the complementizer that is still in $\mathrm{C}^{0}$. 
For non-restrictive/appositive relatives, we follow Demirdache (1991) and assume that the CP is adjoined to a DP, as represented in (23).

(23)

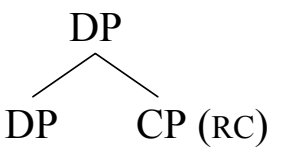

What we have learned from the discussion of phonological phrasing in Bemba in section 4 is that in restrictive relative clauses, regardless of whether the tonal strategy or the segmental relative marker is used, the head noun forms a phonological phrase with the relative clause. In contrast, in non-restrictive relative clauses (which necessarily use a segmental relative marker), the head noun does not form a phonological phrase with the relative clause.

The Kaynian analysis of relative clauses can capture this difference much more naturally than the Standard analysis. This can be seen from the schematic comparison in (24) (using English words to illustrate).

(24) a. Standard analysis

(i) $\quad\left[{ }_{\mathrm{DP}}\left[{ }_{\mathrm{NP}=\mathrm{PPH}}\left[{ }_{\mathrm{NP}}\right.\right.\right.$ Bemba's $]\left[_{\mathrm{CP}=\mathrm{PPH}}\right.$ that are brave $\left.\left.]\right]\right]$ (restrictive relative)

(ii) $\left[{ }_{\mathrm{DP}}\left[{ }_{\mathrm{DP}=\mathrm{PPH}}\right.\right.$ Bemba's $]\left[_{\mathrm{CP}=\mathrm{PPH}}\right.$ that are brave $\left.]\right]$ (non-restrictive relative)

b. Kaynian analysis

(i) $\left[{ }_{\mathrm{DP}}\left[{ }_{\mathrm{CP}=\mathrm{PPH}}\right.\right.$ Bemba's that are brave $\left.\left.]\right]\right] \quad$ (restrictive relative)

(ii) $\left[{ }_{\mathrm{DP}}\left[{ }_{\mathrm{DP}=\mathrm{PPH}}\right.\right.$ Bemba's $]\left[_{\mathrm{CP}=\mathrm{PPH}}\right.$ that are brave $\left.]\right]$ (non-restrictive)

Under the assumption that phonological phrasing is based on syntactic structure and that here specifically left edges of a phrase (XP) determine the left edges of phonological phrases, the standard analysis in (24a) would have two phonological phrases for both restrictive and non-restrictive relatives. This is, for restrictive relatives, clearly contrary to the phrasing as we have seen above.

On the other hand, given a Kaynian analysis (24b), we can capture the phonological phrasing without any extra assumption, since the phrasing predicted is exactly as we have seen. More specifically, in both (24bi) and (24bii) the left edge of a CP coincides with the left edge of a phonological phrase. We can thus conclude that a $\mathrm{CP}$ must coincide with a phonological phrase. This will capture the phonological phrasing in both restrictive and nonrestrictive relatives and clearly allows a better phonology-syntax correspondence: a head noun which is syntactically "internal" (i.e., in CP internal position) forms a phonological phrase with the relative clause, and in contrast, a head noun which is syntactically "external" does not form a phonological phrase with the relative clause. 


\subsection{Headless relatives}

Headless relatives by definition lack an overt head noun and can only be interpreted as restrictive. ${ }^{12}$ Given these facts and considering that the Kaynian analysis of restrictive relatives provides us with a better syntax-phonology correspondence, we simply assume a prosodically empty pronoun to be in SpecCP in headless relatives, as illustrated in (25).
a. ábáshipa na-bá-ya
'those who are brave have gone'
b. [ [DP [cр pro [c'ábáshipa na-bá-ya]]]

Given the representation in (25b), the remaining question is why the tonal strategy is unavailable for headless relatives, given that they share the structure of restrictive relatives. In the next section, we provide an answer to this question by taking into consideration the syntax-phonology interface.

\subsection{The mapping between phonology and syntax}

From the foregoing discussion, we have seen that the tonal strategy of relativization requires a preceding head noun to be phrased together with the low-tone morpheme, so that (26) (repeated from (17b)), which phrases the head noun and the low-tone morpheme separately, is ungrammatical.

$(26) *(\text { abáBemba })_{\mathrm{PPh}}(\text { bà-shipa })_{\mathrm{PPh}}$ (beekala muZambia $)_{\mathrm{PPh}} \quad$ (tonal strategy)

Phonologically this implies that having a phonological phrase boundary immediately preceding the low tone morpheme yields undesirable structures. Following assumptions of Generalized Alignment in Optimality theory (Prince and Smolensky 2004, McCarthy and Prince 1995) this could be formalised as a constraint that bars the relative low tone morpheme from coinciding with a phonological phrase edge. Generalized Alignment is defined in (27).

12 How headless relatives should be analysed syntactically has been a controversial topic. Note that what we posit here may not extend to free relatives in English since the reading of headless relatives in Bemba is not identical to free relatives. 
(27) Generalized Alignment

Where $\mathrm{Cat}_{1}, \mathrm{Cat}_{2}$ are prosodic, morphological, or syntactic categories and $E d g e_{1}, E d g e_{2}$ is a member of \{Right, Left $\}$ :

$\operatorname{ALIGN}\left(\mathrm{Cat}_{1}\right.$, Edge $_{1} ; \mathrm{Cat}_{2}$, Edge $\left._{2}\right)$ iff

For each $\mathrm{Cat}_{1}$ there is a $\mathrm{Cat}_{2}$ such that $E d g e_{1}$ of $\mathrm{Cat}_{1}$ and $E d g e_{2}$ of $\mathrm{Cat}_{2}$ coincide.

Taking (27) into account, we can formulate a constraint such as (28) that militates against the low tone relative morpheme coinciding with a phonological phrase boundary.

*align(RelLow L, Pphr L)

Do not align the relative low tone with the left edge of a phonological phrase.

Working in a framework of ranked and violable constraints this would have to be fairly highly ranked so that its violation results in ungrammaticality. To make this constraint less language specific and hence less ad hoc, we formulate it more generally by referring to low tone in general as in (29). ${ }^{13}$

*align(Low L, Pphr L)

Do not align low tone with the left edge of a phonological phrase.

This, in effect, explains why headless relatives can never be marked with the tonal strategy; they would always begin a phonological phrase with a low tone.

Another apparent phonological effect that we saw in the preceding exposition is that if a head noun is phrased with a following CP (i.e., in restrictives), it is able to host a high tone spreading rightwards by a tone doubling rule whose details are not relevant here. In the inverse case (nonrestrictives), where the head noun is phrased separately from the head the tone doubling rule is blocked and no high tone is seen on the final syllable of the head noun. See, for example, the contrast between (30a) and (30b) (repeated here from (17)).

13 Perhaps this constraint will have to be formulated as a constraint on non-lexical low tones (i.e., grammatical low tones) in order to more easily generalise over the phrasal phonology of the whole language. Pending a full characterisation of Bemba phrasal phonology we are committed to the constraint as it stands and assume that other constraints interacting with *ALIGNLL derive low tone in phrasal initial position in cases where it does occur. 
(30) a. [abáBémbá ábá-shipa $]_{P P h}[\text { beekala muZambia }]_{P P h}$ (segmental REL)

b. [abáBémba $]_{P P h}[a ́ b a ́-s h i p a]_{P P h}[\text { beekala muZambia }]_{P P h}$ (segmental REL)

'Bembas who are brave live in Zambia'

We will account for these facts as a low tone signaling the right edge of a phonological phrase and use a constraint opposite to the one in (29) to account for the distribution as given in $(31) .^{14}$

(31) ALign(Low R, PpHR R)

Align the right edge of a phonological phrase with a low tone

Thus it seems that both right and left edges of phonological phrases are relevant for phrasing in Bemba.

In relating these phonological constraints to syntax we must capture the fact that the relevant left edge that phonology refers to in (29) coincides with a $\mathrm{CP}$ in syntax. To achieve this end we can specify the general constraint of Selkirk (1995) in (32) to a more specific constraint that refers to CPs as in (33).

a. ALIGN-XP, R

For each XP there is a $\mathrm{P}$ (phonological phrase) such that the right edge of XP coincides with the right edge of $P$

b. ALIGN-XP, L

For each XP there is a $\mathrm{P}$ such that the left edge of XP coincides with the left edge of $P$

Align-CP, L

For each $\mathrm{CP}$ there is a $\mathrm{P}$ such that the left edge of that $\mathrm{CP}$ coincides with the left edge of $P$

One caveat with the constraint in (33) is that it violates the Lexical Category Condition (LCC), which bars functional projections like CP and IP from being subject to alignment constraints (Selkirk 1995). One solution would be to formulate the LCC as itself a violable constraint. A second solution, in light of recent proposals in Truckenbrodt (2005), would be to view the relevant left edge

14 The constraint in (31) will be violated by nouns that end in lexical high tones but these nouns would satisfy a higher ranked faithfulness constraint on retaining lexical tones, which an output candidate changing a final lexical high to low in order to satisfy (31), would violate. 
as marking an intonational phrase rather than a phonological phrase. ${ }^{15} \mathrm{We}$, in a sense, adopt both of these views (although we do not formally formulate the former) by postulating that the left edge of CP referred to in (33) must coincide both with a phonological phrase and an intonational phrase. The constraint is thus reformulated as in (34).

Align-CP, L

For each CP there is a $\mathrm{P}$ such that the left edge of that $\mathrm{CP}$ coincides with the left edge of $\mathrm{P}$ iff that $\mathrm{CP}$ also coincides with the left edge of IP (intonational phrase)

In addition we will use the WRAPXP constraint of Truckenbrodt (1999) as a constraint regulating phonological phrasing. The REALMORPH (realize morpheme) constraint will also be relevant and be high ranking so that a relative marker must be realized in relatives. NONRECURSION will also be assumed following Selkirk (1995). These additional constraints are defined in (35).
a. WRAP-XP (Truckenbrodt 1999)
Each XP is contained in a phonological phrase
b. REALMORPH
A relevant morpheme must be realized
c. NONREC (Selkirk 1995)

A P constituent must not contain another $\mathrm{P}$ constituent of the same level

*ALign-Low,L is highest ranked so that it is less preferable to begin phonological phrases with low tone. This is crucial in baring the relative low tone morpheme from occurring at the left edges of phonological phrases. ALIGNCP-L is ranked above WRAP-XP to allow some XPs to escape being wrapped in a phonological phrase just in case they occur in a CP whose left edge coincides with both the left edges of an intonational phrase and a phonological phrase. ALIGN-LowR,PR is the lowest ranked constraint in this partial ranking with the role of determining the right phonological phrase boundaries, ensuring that they do not end in a high tone. Consider the interaction of these constraints in tableau (36) for restrictive relatives under the given ranking. (REALMORPH and NONREC are not shown in the tableaus).

15 Truckenbrodt (2005) regards root clauses, as opposed to embedded clauses, as obligatorily forming intonational phrases. Thus co-ordinated structures with two root clauses are considered as consisting of two intonational phrases. He offers WRAP-CP, which requires each $\mathrm{CP}$ to be contained in an intonational phrase, as the constraint ensuring this phrasing. 
*Align-Low, L » AlignCP-L »WraP-XP » ALIGn-LR,PR Restrictives: ábabémbá ábá-shipa.. 'Bembas who are brave..' ábabémbá bà-shipa..

\begin{tabular}{|c|c|c|c|c|}
\hline ábabémba bá-shipa.. & *ALIGN-LL & AL-CPL & WRAP-XP & A-LR,PR \\
\hline a. $\left([a ́ b a b e ́ m b a]_{\mathrm{NP}}\right)_{\mathrm{P}}\left([\text { bà-shipa }]_{\mathrm{CP}}\right)_{\mathrm{P}}$ & $* !$ & $*$ & & \\
\hline b. $\left([a ́ b a b e ́ m b a ́]_{\mathrm{NP}}\right)_{\mathrm{P}}\left([\text { bà-shipa }]_{\mathrm{CP}}\right)_{\mathrm{P} / \mathrm{IP}}$ & $* !$ & & & * \\
\hline c. $\left(\left[[\text { ábabémbá }]_{\mathrm{NP}} \text { bà-shipa }\right]_{\mathrm{CP}}\right)_{\mathrm{P}}$ & & $* !$ & *NP & \\
\hline d. $\left(\left[[a ́ b a b e ́ m b a ́]_{\mathrm{NP}} \text { bà-shipa }\right]_{\mathrm{CP}}\right)_{\mathrm{P} / \mathrm{IP}}$ & & & *NP & \\
\hline e. $\left(\left[[a ́ b a b e ́ m b a ́]_{\mathrm{NP}} \text { ábá-shipa }\right]_{\mathrm{CP}}\right)_{\mathrm{P} / \mathrm{IP}}$ & & & *NP & \\
\hline
\end{tabular}

Candidates (36a-b) represent the phrasing we would get under the standard analysis where the head noun is external to the relative clause CP. With this syntactic structure, the NP and the CP are in different phonological phrases as we have already pointed out, and hence fatally violate the highly ranked *ALIGN-LL. Thus candidate (36b) that escapes violation of ALIGNCPL by phrasing the $\mathrm{CP}$ with an intonational phrase, is not better off for it. It also incurs the additional violation of ALIGNLR,PR by having a final high tone on the first phonological phrase. Candidates (36c-d) represent the Kaynian analysis where the head noun is internal to the relative clause $\mathrm{CP}$ and therefore results in only one phonological phrase. (36c) escapes violation of the high ranked *ALIGNLL by this phrasing but violates ALIGNCP,L by having the CP in a phonological phrase that does not coincide with an intonational phrase on the left edge. Candidates (36d-e) are the winning candidates representing the tonal relative (36d) and the segmentally marked relative (36e). The phonological phrasing thus seems to favour a syntactic analysis that treats the head noun as internal to the CP. Restrictive object relatives which use the demonstrative based relative marker 'ábo' are treated in the same fashion.

Recall that in object relatives the relative marker is always optional and we have shown that in cases where it is omitted a restrictive interpretation must hold. In these cases (cf. examples in 7-8) ALIGNLR,PR is crucial in showing that because of the high tone on the final syllable of the head noun, no right phonological phrase boundary is present and therefore one phonological phrase is involved, hence the restrictive reading. In this sense, for segmentally marked, tonally marked and non-overtly marked relatives, restrictives are represented as one phonological phrase reflecting the close relation between the head noun and the relative clause manifested in restrictives.

Tableau (37) illustrates non-restrictives, which, as we have shown in earlier discussion, involve separate phrasing of the head noun and the relative 
clause. The winning candidate (37a) avoids the violation of WRAPXP by phrasing the DP in a separate phonological phrase. In addition, unlike candidate (37b) the winning candidate avoids the violation of ALIGNCPL by ensuring that the $\mathrm{CP}$ also coincides with an intonational phrase. Candidate (37c) loses for having a phonological phrase that ends in a high tone. Of course a candidate with no boundary after the head noun is possible but would result in a restrictive interpretation as seen in (36) above.

*ALign-Low, L » ALIGNCP-L »WraP-XP » ALIGn-LR,PR Non-restrictives: ábabémba ábá-shipa.. 'Bembas who are brave..'

\begin{tabular}{||c|c|c|c|c||}
\hline ábabémba ábá-shipa.. & *ALIGN-LL & AL-CPL & WRAP-XP & A-LR,PR \\
\hline b $\left([\text { ábabémba }]_{\mathrm{DP}}\right)_{\mathrm{P}}\left([\text { ábá-shipa }]_{\mathrm{CP}}\right)_{\mathrm{P} / \mathrm{IP}}$ & & & & \\
\hline c. $\left.\left([a ́ b a b e ́ m b a]_{\mathrm{DP}}\right)_{\mathrm{P}}(\text { ábá-shipa..[CP })_{\mathrm{P}}\right]$ & & $* !$ & $*$ & \\
\hline
\end{tabular}

For non-restrictives then, an appositive structure where the DP is a sister to the relative clause CP (as in Demirdache 1991), provides an analysis that is compatible with phonological phrasing.

Compared to the analysis of restrictive and non-restrictive relatives, headless relatives are different because they lack an overt head. In terms of syntactic structure, we have treated headless relatives on a par with restrictives under a Kaynian analysis. However, recall that they share a crucial similarity with non-restrictive relatives, namely, they cannot be formed using the tonal strategy. This results from the fact that they have an empty head which though syntactically active is phonologically empty. With this assumption, the analysis of headless relatives follows straightforwardly from the given constraint ranking, as illustrated in tableau (38).

*Align-Low, L » ALignCP-L »WraP-XP » ALIGn-LR,PR

Headless relatives: ábáishilé maíló.. '(the people) who came yesterday..'

\begin{tabular}{||c|c|c|c|c||}
\hline ábáishile mailo.. & *ALIGN-LL & AL-CPL & WRAP-XP & A-LR,PR \\
\hline a. ([bàishile... $\left.]_{\mathrm{CP}}\right)_{\mathrm{P}}$ & $* !$ & $*$ & & \\
\hline b. ([ábáishile... $\left.]_{\mathrm{CP}}\right)_{\mathrm{P} / \mathrm{IP}}$ & & & & \\
\hline c. ([ábáishile... $\left.]_{\mathrm{CP}}\right)_{\mathrm{P}}$ & & $* !$ & & \\
\hline
\end{tabular}

As we have already pointed out, the tonal morpheme and the segmental relative marker cannot be used simultaneously. Candidate (38a) that uses the tonal morpheme fatally violates high ranked *ALIGNLL for having a low tone at the 
left edge of a phonological phrase. It also violates ALIGNCPL for phrasing a CP into a phonological phrase without an intonational phrase boundary on the left edge. Candidate (38c) suffers this same violation and hence loses despite using the segmental marker and avoiding violation of high ranked *ALIGNLL. Candidate $(38 \mathrm{~b})$ is the winning candidate because unlike (38c) it avoids violation of ALIGNCPL. The winning candidate is as such contained in one phonological phrase and gets a restrictive interpretation. From this we can conclude that it is the phonological phrasing, rather than the use of the tonal morpheme that induces a restrictive versus non-restrictive interpretation of relatives. Furthermore, we can now understand why headless relatives pattern with non-restrictives in being unable to use the tonal marking strategy; both produce phonological phrases that violate *ALIGN-LL.

We can thus conclude that for the mapping between phonology and syntax for restrictive relatives, the Kaynian analysis makes the best phonological predictions. For non-restrictive relatives an appositive structure as in Demirdache (1991) coincides with phonological phrasing. Finally for headless relatives we see that they structurally pattern with restrictives under a Kaynian analysis and hence also get the phonological phrasing of restrictives; however, due to an empty head, they pattern with non-restrictives in being unable to utilise the tonal marking strategy.

\section{Conclusion}

In this paper, we have shown that along side a segmental marking strategy in relativization, a tonal marking strategy is also available in Bemba. Further, based on the contrast between the tonal marking strategy and the segmental marking strategy, we argue that the raising analysis of relativization allows a better syntax-phonology correspondence. In addition, based on the raising analysis, we can also offer an explanation as to why non-restrictive relatives and headless relatives share the property that they do not allow the tonal marking strategy, namely that the low tone morpheme cannot be at the left edge of a phonological phrase aligned with a CP. We therefore show that not only can phonological phrasing be informed by syntactic structure but syntactic analyses can also be informed by phonological phrasing information.

We leave a cross-linguistic comparison and the assessment of whether the constraints here formulated can be seen to be actively operative in other languages, to a future occasion. 


\section{$7 \quad$ References}

Bianchi, V. (2000) The raising analysis of relative clauses: a reply to Borsley. Linguistic Inquiry 31:123-140.

Boersma, P. \& D. Weenink (2005) Praat: doing phonetics by computer (version 4.4.02). http://www.praat.org.

Demirdache, H. (1991) Resumptive chains in restrictive relatives, appositives, and dislocation structures. MIT: PhD Dissertation.

Demuth, K. \& C. Harford (1999) Verb raising and subject inversion in comparative Bantu. Journal of African Languages and Linguistics 20: 41-61.

Givón, T. (1972) Studies in chiBemba and Bantu grammar. Studies in African Linguistics. Supplement 3.

Grosu, A. \& F. Landman (1998) Strange relatives of the third kind. Natural Language Semantics 6:125-170.

Harford, C. \& K. Demuth (1999) Prosody outranks syntax: an Optimality approach to subject inversion in Bantu Relatives. Linguistic Analysis 29: 47-68.

Kamwangamalu, N.M. (1988) 'C-command' and the phonology-syntax interface in Ciluba. Studies in the Linguistic Sciences 18.2: 87-109.

Kanerva, J.M. (1990) Focus and phrasing in Chichewa phonology. New York: Garland.

Kayne, R. (1994) The Antisymmetry of Syntax. Cambridge, Mass: MIT Press.

Kimenyi, A. (1978) A relational grammar of Kinyarwanda. Berkeley: University of California Press.

Kula, N.C. (in prep.) Phonological phrasing in Bemba. Ms., University of Leiden.

McCarthy, J. \& A. Prince (1995) Generalized Alignment. Yearbook of Morphology: 79-153.

Meeussen, A.E. (1971) Relative clauses in Bantu. Studies in African Linguistics. Supplement 2: $3-10$.

Nespor, M. \& I. Vogel (1986) Prosodic Phonology. Dordrecht: Foris.

Nsuka, N.F. (1982) Les structures fondamentales du relatif dans les langues Bantues. Tervuren: Musee Royal de 1'Afrique Centrale. Annales-Serie 8, Sciences Humaines 108.

Oger, L. (1979) Learn Bemba the easy way. Illondola, Chinsali: Language Centre.

Prince, A. \& P. Smolensky (2004) Optimality Theory: Constraint interaction in generative grammar. McCarthy, J. (ed.) Optimality Theory in phonology. Oxford: Blackwell Publishing, 3-71.

Sambeek, J. van (1955) A Bemba Grammar. London: Longmans, Green and Co. 
Selkirk, E. (1984) Phonology and Syntax: the relation between sound and structure. Cambridge: MIT Press.

Selkirk, E. (1995) The prosodic structure of prosodic words. University of Massachusetts Occasional Papers 18: Papers in Optimality Theory: 439-469. GLSA, University of Massachusetts, Amherst.

Sharman, J.C. (1956) The tabulation of tenses in a Bantu language (Bemba: Northern Rhodesia). Africa 26: 29-46.

Sharman, J.C. \& A.E. Meeussen (1955) The representation of structural tones, with special reference to the tonal behaviour of the verb in Bemba, Northern Rhodesia. Africa 25: 293-404.

Truckenbrodt, H. (2005) A short report on intonation phrase boundaries in German. Linguistische Berichte 203: 273-296.

Truckenbrodt, H. (1999) On the relation between Syntactic Phrases and Phonological Phrases. Linguistic Inquiry 30.2: 219-255.

Walusimbi, L. (1996) Relative clauses in Luganda. Cologne: Rüdiger Köppe Verlag.

L.L.Cheng@let.leidenuniv.nl

N.C.Kula@let.leidenuniv.nl 